\title{
Isolation and Characterization of DNA from Root
} Tubers

\author{
O. G. Dawodu ${ }^{1^{*}}$, O. R. Agbeni ${ }^{1}$ and V. Iwu ${ }^{2}$ \\ ${ }^{1}$ Department of Science Laboratory Technology, Federal Polytechnic Ede, Osun State, Nigeria. \\ ${ }^{2}$ Department of Bioscience, IITA, Ibadan, Nigeria.
}

\begin{abstract}
Authors' contributions
This work was carried out in collaboration among all authors. Author OGD designed the study, performed the statistical analysis, wrote the protocol and wrote the first draft of the manuscript. Authors ORA and VI managed the analyses of the study. Author VI managed the literature searches. All authors read and approved the final manuscript.

Article Information

DOI: $10.9734 / A R R B / 2020 / v 35 i 230189$ Editor(s):

(1) Dr. Md. Torequl Islam, Federal University of Piaui, Brazil.

Reviewers:

(1) Maria Bintang, IPB University (Bogor Agricultural University), Indonesia.

(2) Jayath P. Kirthisinghe, University of Peradeniya, Sri Lanka. Complete Peer review History: http://www.sdiarticle4.com/review-history/54906
\end{abstract}

Original Research Article

Received 20 December 2019

Accepted 25 February 2020

Published 11 April 2020

\begin{abstract}
This study reports a modified SDS extraction technique for isolation of DNA from root tubers namely Dioscorea (yam), Manihot esculenta (cassava) and Colocasia esculenta (cocoyam). DNA extraction in many plants is very difficult because of secondary metabolites that interfere with DNA isolation procedure. Young fresh leaves were collected from the selected tubers and DNA extracted using SDS-extraction protocol, the DNA isolated from the extracted leaves was subjected to gel electrophoresis for determining their purity and concentration and PCR amplification was carried out on the extracted DNA, afterwards gel-electrophoresis was performed for molecular weight determination of the samples. DNA sequencing were performed on both reverse and forward using Sanger sequencing method which gave the nucleotide bases of the samples. DNA isolated by modified SDS protocol method was pure and highest level of purity was obtained from Manihot esculenta, Colocasia esculenta and Dioscorea which are 1.77, 1.72 and 1.20 with concentration of $537.7 \mathrm{ng} / \mu \mathrm{l}, 992.4 \mathrm{ng} / \mu \mathrm{l}$ and $149.8 \mathrm{ng} / \mu \mathrm{l}$ respectively.

The DNA isolated from root tubers was pure and of good quality, and the isolated DNA was characterized by sequencing. The isolated DNA was successfully sequenced which coded for marker genes of the respective root tubers.
\end{abstract}

*Corresponding author: E-mail: dawgrace@yahoo.com, dawodu.olufunke@federalpolyede.edu.ng; 
Keywords: DNA characterization; DNA isolation; PCR amplification; root tubers.

\section{INTRODUCTION}

Root tubers serves as sustenance for millions of people in the tropical and sub-tropical world [1]. They save mankind in times of famine, even during starvation. There are different kinds or root tubers, which serves as consumption for human. Cassava is the most dominant root crop; however, yam, cocoyam and plantain are also important crops. The use of root tubers as a tool for isolating DNA is highly desirable for developing an easy integrating of new genetic material to satisfy market needs and also helps develop genotypes possessing tolerance against diverse biotic and abiotic challenges. A necessity for successful implementation of these crops improvement ways is the ability to isolate good amount of high quality DNA which can be for polymerase chain reaction (PCR) amplification $[2,3]$. The isolation of good quality DNA from plant materials of tubers is very challenging due to presence of polysaccharides and phenolic compounds are the two classes of plant biomolecules that are very widely between species and very problematic when isolating DNA. During tissue homogenization, phenolics become oxidized and bind to the protein and nucleic acid [4].

The binding produces a gelatinous material which is hard to separate from organelles and the DNA becomes unsuitable for PCR implication (Porebskki, et al. 1997). Polysaccharides are also problematic and can interfere with manipulation of DNA following isolation. The problem of polyphenols is worse if green, over matured tissue is taken rather than fresh and young tissues (Sharma, et al. 2000).

Extraction of a suitable quantity and quality of DNA is a critical step in molecular applications, such as polymerase chain reaction (PCR) and sequencing. Several protocols have been established for DNA extraction, some of which are applicable on wide range of materials and some are specific to a particular tissue type [5-8]. Generally freshly harvested leaves are preferred for extraction of DNA [9]. In addition, extraction of DNA from preserved leaf tissues, seeds, stems, and tubers is not uncommon. However, the presence of polysaccharides, tannins and other metabolites with high affinity to DNA and protein in these tissues makes it difficult to extract good quality DNA for further utilization in molecular techniques.
Polysaccharides inhibit the action of Taq polymerase, thus affecting the PCR reaction process [10].

A number of studies have been carried out in the past to establish protocols for the extraction of good quality DNA from tubers [10] and other tissues. In this study, several available protocols were evaluated to extract good quality DNA from a wide array of tissues, with the aim of developing a technically simple, rapid, and costeffective protocol for manual and high-throughput DNA extraction using automated tissue grinders. The aim of the study is to isolate and characterize DNA from plant materials (root tubers).

\section{MATERIALS AND METHODS}

\subsection{Sample Collection}

Fresh young leaves of different root tubers namely:-cocoyam, yam and cassava were obtained from Ede, Osun state.

\subsection{Plant Materials}

Young leaf tissues of Yam (Dioscorea), Cassava (Manihot esculenta) and Cocoyam (Colocasia esculenta) were collected. These were kept in sample bottles with silica gel and kept away from moisture and light until transportation to the IITA labs.

\subsection{List of Equipment Used}

Polymerase chain reaction (PCR), Electrophoresis, incubator, centrifuge, Nanodrop 8000 spectrophotometer.

\subsection{DNA Isolation, PCR Amplification and Characterization}

This was done at the Bioscience Labs IITA Ibadan Nigeria.

\subsection{Preparation of 100ML SDS Extraction Buffer}

$10 \mathrm{ml}$ of $1 \mathrm{M}$ Tris-HCL, $10 \mathrm{ml}$ of $0.5 \mathrm{M}$ EDTA, 10 $\mathrm{ml}$ of $5 \mathrm{M} \mathrm{NaCl}, 20 \%$ of SDS ( $20 \mathrm{~g}), 1 \%$ PVP (1 g) and Mercaptoethanol- $1 \%$ added immediately prior to use make up to $100 \mathrm{ml}$ with distilled water. 


\subsection{DNA Extraction Protocol}

- All materials used were sterilized appropriately.

- Samples were prepared by putting approximately $100 \mathrm{mg}$ of freeze dried tissues into an extraction tubes and the tubes were labeled sample A, B, C respectively.

- Two steel balls each were added into the tubes to enable grinding.

- The freeze dried tissue was grounded into fine powder by using Genogrinder-2000.

- $450 \mu \mathrm{l}$ of pre-heated plant extraction buffer was added.

- The tubes were incubated at $65^{\circ} \mathrm{c}$ for 20 minutes and mixed by occasionally inverting the tubes to homogenize the samples.

- The tubes were removed and allowed to cool for 2 minutes; $200 \mu$ of ice-cold $5 \mathrm{M}$ Potassium acetate was added.

- It was incubated on ice for 20 minutes to precipitate protein, centrifuged at 10000 rpm for 10 min and the supernatant was then transferred into freshly labeled tubed.

- $\quad 450 \mu$ l of chloroform Isoamylalcohol (24:1) was added and was also mixed gently to further precipitate protein and lipids.

- It was centrifuged at $10000 \mathrm{rpm}$ for 10 minutes and the supernatant was transferred into freshly labeled tubes.

- 2/3 volume of ice cold Isopropanol was added, mixed gently and it was incubated in $80^{\circ} \mathrm{C}$ for 15 mins to precipitate the DNA.

- It was centrifuged at $100000 \mathrm{rpm}$ for 10 min.

- The supernatant was decanted until the last drop and the pellet was air dried. (Until ethanol smell disappears)

- $60 \mu$ l of ultra-pure water or low salt TE was added to re-suspend the DNA.

- $2 \mu \mathrm{l}$ of RNase and was Added and incubated in $37^{\circ} \mathrm{C}$ for $30-40$ mins.

\subsection{DNA Analysis}

The quality of extracted DNA was analyzed by means of agarose gel electrophoresis (0.8) was prepared for checking DNA quality and removal of RNA (0.8 gram of agarose in $100 \mathrm{ml}$ of $1 \mathrm{X}$ TBE, cool to about $60^{\circ} \mathrm{C}$ and $5 \mu$ ethidium bromide was added and gently swim to mix; it was poured on the gel tray before it polymerizes. There shouldn't be air bubbles in the middle of the gel. $3 \mu \mathrm{l}$ of DNA and $3 \mu \mathrm{l}$ of loading dye was mixed. It was briefly spinned to collect to the bottom of the plate and $6 \mu \mathrm{l}$ of this mix was loaded on to the $0.8 \%$ agarose gel. The gel was run at 80 volts for about 60 mins. The gels picture was saved. The RNA was checked whether it has been completely removed to proceed to the Nano drop step.

\subsection{DNA Purity and Concentration}

Quantify DNA Concentration using DNA-50 option of the Nano drop spectrophotometer. Approximately 1.8 ratios for sample absorbance at $A_{260 / 280}$ is generally accepted as "pure" for DNA. $A_{260 / 230}$ ratio is a secondary measure of nucleic acid purity for the presence/absence of co-purified contaminants. $A_{260 / 230}$ ratio of 1.8-2.2 is generally acceptable.

\section{RESULTS}

\subsection{DNA Yield and Purity}

DNA isolated using SDS-extraction protocol gave a high DNA yield from leaf samples of root tubers (Cassava, Yam, Cocoyam). The purity and concentration of DNA was further confirmed by the means of using NanoDrop 8000 Spectrophotometry by opening the NanoDrop application. The results from NanoDrop Spectrophotometry showed that they yielded a good quality and quantity of DNA. Approximately 1.8-2.0 for sample absorbance at $A_{260 / 280}$ is generally accepted as "pure" for DNA. Purity and concentration results were shown in Table 1 . The concentration of DNA yielded $527.7 \mathrm{ng} / \mu \mathrm{l}$ of Cassava, $149.8 \mathrm{ng} / \mu \mathrm{l}$ of $\mathrm{Yam}$ and $992.4 \mathrm{ng} / \mathrm{\mu l}$ of Cocoyam. The $A_{260 / 280}$ ratio was 1.77 for DNA extracted from Cassava, 1.20 for DNA extracted from Yam and $1.72 \mathrm{ng} / \mu \mathrm{l}$ for DNA extracted from Cocoyam (Table 1).

\subsection{DNA Analysis}

The quality of extracted DNA was analyzed by means of agarose gel electrophoresis $(0.8 \%)$, bands were visualized after loading the samples in the tank. The samples were of good quality (Fig. 1).

\subsection{PCR Amplification}

After the DNA was successfully isolated and viewed using the agarose gel electrophoresis which is used in determining the maxiamplification of DNA. The DNA extracted from root tubers leaf samples was amplified by using H1f F: CCACAAACAGAGACTAAAGC and 
Fofana R: GTAAAATCAAGTCCACCGCG primers. Successful and reproducible amplifications were obtained. . The results demonstrated that DNA extracted with the SDS extraction protocol is suitable for PCR-based analysis shown in (Fig. 2). PCR amplification was carried out in GeneAmp PCR System 9700.

\subsection{How about the Yam???}

The PCR amplification for the yam failed hence no report was given from this end.

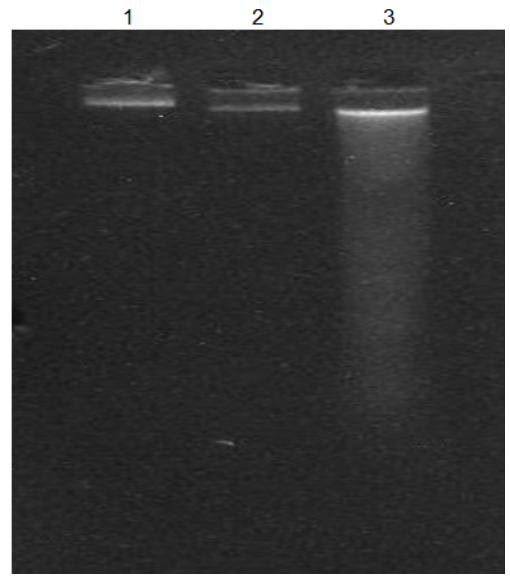

Fig. 1. Lane1: Cassava, 2: Yam, 3: Cocoyam

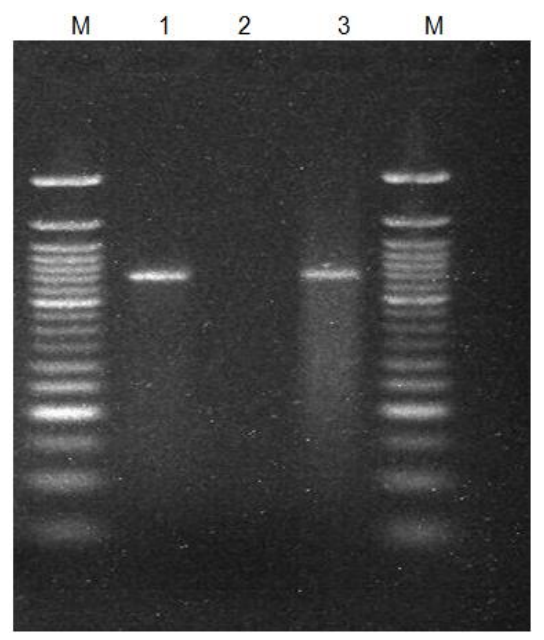

Fig. 2. PCR analysis conducted with the DNA isolated

Amplification of DNA by PCR using H1f $F$ and Fofana $R$ primers. Lanes - 1. Cassava; 2. Yam; 3. Cocoyam. Lane M, 1 kb DNA marker (New England Biolab)

\subsection{Sequence Analysis}

Sanger sequencing was performed using 3130XL genetic analyzer from Applied
Biosystems. Marker gene was sequenced that identified Manihot esculenta, Colocasia esculenta. They gave different organisms that are similar to each samples.

Manihot esculenta sequencing was blasted which yielded six (6) different genomes shown in the Table 2:

Manihot esculenta rubulose-1,5-biphosphate carboxylase/oxygenase.

Manihot esulenta chloroplast rbcL gene for Rubisco Large subunit.

Manihot esulenta cultivar TME3 chloroplast, complete genome.

Manihot esulenta chloroplast rbcL gene for ribulose-1,5-biphosphate.;

Manihot esulenta voucher BioBot05394 ribulose1,5-biphosphate.

Manihot esulenta isolate DNAS- 317-250117 ribulose-1,5-biphosphate.

Colocasia esculenta sequencing was also blasted which yielded six (6) different genomes shown below:

Colocasia esculenta voucher BioBor05394 ribulose-01,5-biphosphate.

Colocasia esculenta ribulose-1,5-biphosphate carboxylase/oxygenase.

Colocasia esculenta voucher Chase, 10669, (k) ribulose-1,5-biphosphate.

Colocasia esculenta isolate RR chloroplast, complete genome.

Colocasia esculenta isolate GP chloroplast, complete genome.

\section{Cassava (Manihot esculenta)}

TGTTACGTCAAAACAGAGACTAAGCGCGGTG GACTTGATTTTACACGTCCACAAATAGAGACT AAAGCGCGGTGTACTTGATTTTACACGTCCA CAAACAGAGACTAAAGCGCGGTGGACTTGAT TTTACAGCTGAACCTTCTAATGCTACATGGCC GAGTGTGTGGATTGATGGACTTACCAGTCTT GATCGTTATAAAGGACGATGCTACGGCCTCG AGCCCGTTCCTGGAGAAGAAAATCAATATAT TGCTTATGTAGCTTACCCATTAGACCTTTTTG AAGAAGGTTCTGTTACTAACATGTTTACTTCT 
ATTGTGGGTAATGTATTTGGGTTCAAAGCCC TACGCGCCCTACGTCTGGAGGATTTGCGAGT CCCTCCTGCTTATTCTAAAACTTTCCAAGGCC TCCTCATGGCATCCAAGTTGAGAGAGATAAA TTGAACAAGTATGGTCGCCCCCTATTAGGTT GTACTATTAAACCAAAATTGGGGCTATCCGC TAAGAATTACGGTAGAGCAGTTTATGAATGTC TTCGCGGTGGATTGAATTTTACACGTCCACA AAACAGAGACTCAAGCGCGGTGTACTTTTTT TTTACACACGCACACACAGAGACACTAGCGC GCGGTGCTTTTTTTTTTCACACGTAAAAAAAGA GACACGAGGGTGGTCTTTTTTTTTTGAACACG ACAAAAAAAAGACCACCACCGCGCTGTGTAT TTTTATGTAAAATGTCAAAAAAAAAGACCAGC ATCTTTCACTTGTCTTTTGTGCAGCTCATACG CAGC.

\section{Cocoyam (Colocasia esculenta)}

TATTTTCAGCAGAGTACGTCAAACAGAGACT AAGCGCGTAGGACTTGATTTTACACGTCCAC AACAGAGACTAAAGCGCGCAGTACTTGAATT TACTCGTCCCGGACAGAGACTAAAGCGCCAT GGGCTGCATTTTACACGTCATCTTCTACTGG TACATGGACAACTGTGTGGACTTGACGGACT TACCAGTCTTGATCGTTACAAAGGACGATGC TACCACATCGAAGCCGTTGTTGGGGAGGAAA ATCAATATATTTCTTATGTAGCTTACCCTTTAG ACCTTTTTGAAGAAGGTTCTGTTACTAACATG TTTACTTCTATTGTAGGTAATGTATTTGGGTT TAAAGCTTTACGAGCTCTACGTCTGGAGGAT TTGCGAATTCCTACCTCTTATTCCAAAACTTT CCAAGGCCCGCCTCACGGTATCCAAGTTGAA AGAGATAAATTGAACAAGTATGGTCGTCCCC TATTGGGATGTACGATTAAACCAAAATTGGG ATTATCCGCGAAAAACTACGGTAGAGCGGTT TATGAATGTCTTTGCGGTGGACTTGATTTTAC TCGCCCACAAAAAGAGCCCCCGGCGTCGTT GGTTCTTTTTTTTTACACTCACAACAACTCCGC CTGCCTCGTGTTCTGTTGTTGTAACGAGAAA AGAAACTCCATC.

\section{DISCUSSION}

The basic purpose of this study was to isolate DNA with a protocol that can be applied to most root tubers which can yield large amount of pure, intact DNA for PCR amplification and sequencing. The DNA extraction protocol described here is rapid and technically easy for preparing nucleic acid that is useful as an amplification target. The same protocol can be scaled up if need to go for large-scale extractions and this method can also be attempted to other crops where extraction of pure DNA for PCR and can also be used for Restriction enzymes.

In this study, SDS-Extraction protocol was used. The protocol developed has several advantages namely:- The SDS detergent used breaks up the lipids in the membranes, the protocol gave sufficient amount of DNA, it also facilitated good quality DNA obtained from different plants tissues. This protocol successfully isolated DNA from several plant species, including yam, cassava, cocoyam, from which genomic DNA isolation is difficult due to presence of a high amount of polyphenolic compounds and proteins [11]. The procedure also works well with most of the genera of root tubers and this method is simple and not labor expensive. In addition, the protocol was carried out in Eppendorf tubes, hence the chances of contamination and loss of DNA was minimized. SDS is the preferred option in order to obtain good quality DNA $[12,13]$.

The key steps of SDS protocol recommend the freeze-dried tissue for easy grinding; the extraction buffer was used with SDS. The extraction buffer contains proteinase $\mathrm{K}$ and PEG which removes proteins and polyphenolic compounds completely.

Table 1. DNA yield and purity isolated from different root tubers

\begin{tabular}{llll}
\hline sample & DNA Concentartion $(\mathbf{n g} / \boldsymbol{\mu l})$ & $\mathbf{A}_{\mathbf{2 6 0 / 2 8 0}}$ & $\mathbf{A}_{\mathbf{2 6 0 / 2 3 0}}$ \\
\hline cassava & 527.7 & 1.77 & 1.09 \\
Yam & 149.8 & 1.20 & 0.29 \\
Cocoyam & 992.4 & 1.72 & 1.05 \\
\hline
\end{tabular}

Table 2. Details of PCR targets

\begin{tabular}{|c|c|c|c|}
\hline Species & $\begin{array}{l}\text { No of nucleotide } \\
\text { bases }\end{array}$ & $\begin{array}{l}\text { Primer name }\left(5^{1} \text { to } 3^{1}\right) \text { for plant } \\
\text { charaterization }\end{array}$ & Molecular Typ \\
\hline Cassava & 793 & H1f F: CCACAAACAGAGA & DNA \\
\hline Cocoyam & 670 & $\begin{array}{l}\text { Fofana R: GTAAAATCAAG } \\
\text { TCCACCGCG }\end{array}$ & DNA \\
\hline
\end{tabular}


The results from NanoDrop Spectrophotometry showed that the protocol described in this study yielded a good quality and quantity of DNA (Table 1). The concentration of DNA yielded $527.7 \mathrm{ng} / \mu \mathrm{l}$ of cassava, $149.8 \mathrm{ng} / \mu \mathrm{l}$ of yam and $992.4 \mathrm{ng} / \mu \mathrm{l}$ of cocoyam. The $\mathrm{A}_{260 / 280}$ ratio was 1.77 for DNA extracted from cassava, 1.20 for DNA extracted from yam and 1.72 for DNA extracted from cocoyam. It was observed that the addition of PEG (polyethylene glycol) in the extracted buffer increased the quality of DNA; this may be due to the effective removal of polysaccharides present in the samples. PEG is regularly used for tissue samples which are known to contain high amounts of polysaccharides [14].

The isolated DNA was amplified using $\mathrm{H} 1 \mathrm{f} F$ and Fofana R Primers (Table 2). Amplification of the isolated DNA confirmed that the quality of DNA extracted using the protocol was suitable for PCR amplification (Fig. 2). This study demonstrated the technique as a simple and efficient to extracting DNA for PCR amplification from many plant species.

The DNA isolated was sequenced using Sanger sequencing and upon sequencing, and gave 793 (cassava) and 670 (cocoyam) nucleotides respectively (Table 2) and Marker genes were sequenced that identified the samples to their specie levels.

\section{CONCLUSION}

It can be clearly seen from this research that DNA from root tubers were isolated and characterized. The DNA extraction protocol used in this research were able to obtain high quality genomic DNA from the root tubers. Purity and concentration of the samples were further confirmed by NanoDrop spectrophotometer which gave high yield on both cassava and cocoyam and yam. Sanger sequencing were performed which was used to know the sequence of the nucleotides bases in the respectivr samples. DNA isolated was a marker gene which identified to the species level the tubers used for the study.

\section{RECOMMENDATION}

This research is worthwhile and therefore should not be abandoned, but rather be improved for proper understanding.

The government should interfere in agricultural resources in order to improve market supply and also public enlightenment should be organized to know the importance and also for the industries to utilize them.

The isolation method can be used for restriction digestion, PCR based marker studies and screening of transgenic plants.

The same protocol can be scaled-up if for largescale extractions and can be attempted to other crops.

\section{COMPETING INTERESTS}

Authors have declared that no competing interests exist.

\section{REFERENCES}

1. Sreecha Chandran N, Prabha Kumari C, John S. Molecular characterization of anthocyanin synthase gene of purple and white fleshed variance of Dioscorea alata. Intl. J. Res. Pharm. Chem. 2018;8(2):390393.

2. Sharma K, Bhattacharjee R, Sartie A, Lava Kumar P. An improved method of DNA extraction from plants for pathogen detection and genotyping by polymerase chain reaction. Afr. J. Biotech. 2013; 12(15):1894-1901.

3. Visalakshichandra MN, Sheela AS, Swathy BS, Prakash K, Vivek H. Comparative assessment and optimisation of different DNA extraction methods in lesser Yam Dioscorea esculenta. Int. J. Curr. Microbiol. App. Sci. 2018;7(7):4308-4318

4. Aljanabi SM, Forget L, Dookun A. An improved rapid protocol for the isolation of polysaccharides and polyphenols-free sugarcane DNA. Plant Mol. Biol. Rep. 1999;17:1-8.

5. Amani J, Kazemi R, Abbasi AR, Salmanian $\mathrm{AH}$. A simple and rapid leaf genomic DNA extraction method for polymerase chain reaction analysis. Iran. J. Biotechnol. 2011; 9(1):69-71.

6. Carrier G, Santoni S, Rodier-Goud M, Canaguier A, De Kochko A, DubreuilTranchant C, This P Boursiquot JM, Cunff LL. An efficient and rapid protocol for plant nuclear DNA preparation suitable for next generation sequencing methods. Am. J. Bot. 2011;98(1):e13-e15.

7. Pervaiz ZH, Turi NA, Khaliq I, Rabbani MA, Malik SA. A modified method for high- 
quality DNA extraction for molecular analysis in cereal plants. Genet. Mol. Res. 2011;10(3):1669-1673.

8. Akkurt M Comparison between modified DNA extraction protocols and commercial isolation kits in grapevine (Vitis vinifera L.). Genet. Mol. Res. 2012;11(3):23432351.

9. Zhang J, Stewart JM. Economical and rapid method for extracting cotton genomic DNA. J. Cotton Sci. 2000;4:193201.

10. Wulff EG, Torres S, Vigil EG. Protocol for DNA extraction from potato tubers. Plant Mol. Biol. Rep. 2002;20:187a-187e.

11. Cassago A, Panepucci RA, Baião AMT, Henrique-silva F. Cellophane based miniprep method for DNA extraction from the filamentous fungus Trichoderma reesei. BMC Microbiology. 2002;2:14.

12. Keb Llanes M, Gonzalez G, ChiManzanero $B$, Infante $D$. A rapid and simple method for small scale DNA extraction in Agavaceae and other tropical plants. Plant Mol. Biol. Rep. 2002;20:299a299 e.

13. Matasyoh LG, Wachira FN, Kinyua MG. Muigai AWT, Mukiama TK. Leaf storage conditions and genomic DNA isolation efficiency in Ocimum gratissimum L. from Kenya. Afr. J. Biotech. 2008; 7(5):557-564.

14. Sharma K, Mishra AK, Mishra RS. A simple and efficient method for extraction of genomic DNA from tropical tuber crops. Afr. J. Biotechnology. 2008;7:1018-1022.

(C) 2020 Dawodu et al.; This is an Open Access article distributed under the terms of the Creative Commons Attribution License (http://creativecommons.org/licenses/by/4.0), which permits unrestricted use, distribution, and reproduction in any medium, provided the original work is properly cited.

Peer-review history:

The peer review history for this paper can be accessed here: http://www.sdiarticle4.com/review-history/54906 